\title{
GENDER AND AGE: LANGUAGE USE IN TV SERIES \& THE IMPACT TO ENGLISH LEARNING
}

\author{
Marisa Fran Lina \\ IAIN Salatiga \\ marisafl@iainsalatiga.ac.id \\ Wildan Nur Hidayat \\ IAIN Salatiga \\ andariwaniiwildan@gmail.com
}

Submission
Track:
Received:
21-10-2019
Available online:
31-10-2019
Corresponding
Author:
Marisa Fran Lina
marisafl@iainsalatiga.ac.id

\begin{abstract}
The purpose of the research is to find out the use of language in $T V$ series in the perspective of gender and age. It is also found the differences and similarities among adult male, female and older people use the non-standard language. This research used a method of descriptive qualitative research, since it analyzes all the script on the TV series. The sample of the study is consisted of 2 parts which are divided into gender and age perspectives based on the underlying theories. The conversations were categorized as: two languages (Bahasa Indonesia or the original language of the TV series and English as the translation). The dialogs are also divided into standard language and non-standard language among adult males, females and older man (parents). Then, the findings of the research shows that Labov's theory is rejected by Olive and Tara's dialect in the dialog, but they support the statement of Aldous Huxley. Then, the utterances of Olive's Father, it violates Downes's theory who says that between the ages of 25 and 60 people choose standard as opposed to dialectical forms most frequently. Besides, by learning this journal, it is hoped that this article can be an example to the young generation early so that they do not participate in the decay of standard language specifically when they use in academic context.
\end{abstract}

Keywords: Gender, Age, TV series, English Learning

\section{INTRODUCTION}


As Aldous Huxley in Two or Three Graces in the Coulmas's Book (p.36) states that "In the eighteen century, when logic and science were the fashion, women tried to talk like the men. The twentieth century has reversed the process". Indeed, nowadays many women speak like men speak. Moreover, there is women's emancipation in which puts women in various position of jobs. It is enable women to interact with others and specifically men, then imitate their speech in order to be more easier to understand in communications. However, it is contradictory with this statement that will be the underlying theory; Labov (1990: 210) confirms women tend to choose the standard variants more frequently than men. It is located on chapter 3 of Coulmas's Book (Gender) page 40. Why it is in contrast with the first statement? Because here, women's speech does not change or does not talk like men. The reason is men tend to use non standard language meanwhile women is the otherwise. In detail, men in English speech often reduce when they speaks walking, running, eating, etc so they say walkin', runnin' and eatin'. Other finding (Trudgill: 1984) shows that -in form is mostly used by male rather than female and the higher social status is the lower frequency of using -in form. Therefore, this Labov's statement will be used to analyse facts in daily life as the findings of this paper. It is to define whether this statement is in line with the findings or opposed instead.

Furthermore, the second essential statement that will be applied is adapted from Downes (1984: 191) who says that between the ages of 25 and 60 people choose standard as opposed to dialectical forms most frequently (Coulmas: Chapter 4-Age, page 61). According to the Coulmas's book (p.61), as people grow older, their speech becomes less dialectical and converges toward the standard. If it is used in Indonesia, it means that people around those ages (adulthood) tend to use Standard Indonesian rather than non-standard/dialectical Indonesian. On the other hand, does this phenomenon always exist in every setting and context? It will be answered after comparing this theory to the facts found.

Meanwhile, the use of standard language is usually used in English learning context. By studying this article, it is hoped that especially students can learn the style of standard language which they can use in academic context. They also can differentiate between non-standard language specifically slang language and standard language. It is line with Rahayu (2015: 1) who says that language is very closely related to the culture of a generation. If the generation 
of this country is increasingly immersed in fading Bahasa Indonesia, maybe Bahasa Indonesia will be increasingly staggered in shouldering the burden as a national language and national identity. In such conditions, it is necessary to provide guidance and fertilization to the young generation early so that they do not participate in the decay. The influence of the current of globalization in national identity is reflected in the behavior of people who are starting to leave Bahasa Indonesia and are accustomed to use slang. At present, it is clear in the community that there is already a lot of use of slang and this is compounded by the Indonesian younger generation who are also inseparable from the use of slang. In fact, this young generation uses the most and creates slang in the community. Another phenomenon is the language of Alay which is often used in social media and daily conversation. Shifts in word structure that occurs in the present and it is carried out by many groups to form the emergence of new vocabulary that marginalizes formality in language. The use of Bahasa Indonesia here means the use of standard language and the use of slang and alay language mean non-standard language that are blooming in youth level nowadays.

For those reasons, the writer selects one of TV Series in Kompas TV namely "Malam Minggu Miko" or "Miko's Saturday Night" entitled "Mobil, Olive dan Tara” (The Car, Olive and Tara). The writer would like to analyze dialogs and situations seen in the episode using those underlying theories. Then, she is going to infer whether those theories support or not toward the findings.

\section{THEORETICAL FRAMEWORK}

\section{Standard Variants of Language}

Most languages have a standard variety; that is, some variety that is selected and promoted by either legal authorities or other social institutions, such as schools or media. Standard varieties are more prestigious than other, nonstandard varieties and are generally thought of as "correct" by speakers of the language. The standard varieties are only "correct" in the sense that they are highly valued within the society that uses the language. As Ralph Harold Fasold (2006) puts it, "The standard language may not even be the best possible 
constellation of linguistic features available. It is general social acceptance that gives us a workable arbitrary standard, not any inherent superiority of the characteristics it specifies." Additionally, Trudgill defines (1999) sociolinguists generally recognize the standard variety of a language as one of the dialects of that language.

\section{Language and Gender}

Language and gender is an area of study within sociolinguistics, applied linguistics, and related fields that investigates varieties of speech associated with a particular gender, or social norms for such gendered language use (Tannen: 2006). A variety of speech (or sociolect) associated with a particular gender is sometimes called a genderlect.

The difference between women and men language is an approach of equality, it is belonging to different 'sub-cultures' as they have been socialized to do so since childhood. This then results in the varying communicative styles of men and women (Tannen 1990). She compares gender differences in language to cultural differences.

Women are generally believed to speak a better "language" then men do. This is a constant misconception, but scholars believe that no gender speaks a better language, but that each gender instead speaks its own unique language (Azizi: 2011). This notion has sparked further research into the study of the differences between the way men and women communicate.

\section{Language and Age}

Based on a research did by Argamon, et al. (2007), they reported that their analysis of a great corpus of blog postings to know whether and how writing topic and style different with age and gender of the writer in the blog. Pennebaker, et al. (2003) stated that it has also recently been indicated that writing topic and style are beneficial signs of age-linked psychological developments in the aspescts of personality, interests, and feelings. Their corpus has over 140 million words of text from randomly chosen blogs by men and women from their adolescents into their forties. By implementing factor analysis and machine learning techniques, they demonstrate here obvious and consistent patterns of age- and gender-related variation in writing topic and style. They find that older bloggers incline to write about externally-focused topics, meanwhile younger bloggers incline to write about more individually-focused topics; 
changes in writing style with age are much related. Perhaps surprisingly, same patterns also characterize gender-related differences in language style. Obviously, the linguistic factors that develop in use with age are only applied more by males of any age, and on the contrary, those that lessen in use with age are those applied more by females of any age. Thus, their results underline and generalize earlier results on age-linked (Pennebaker and Stone, 2003;Burger and Henderson, 2006; Pennebaker, et al., 2003) and gender-linked (Argamon, et al., 2003; Biber, 1994; Newman, et al., in press) variation in language use. They suggest that their results are best explained by placing a single factor differentiating internal from external psychological focus that highlights both age- and gender-related variation in language use. Preliminary results with these lines were previously shown by the authors in (Schler, et al., 2006).

\section{Correlating Age and Gender}

It has not lost the attention that with bit exceptions, the factors and class of words that are used importantly more by younger (older) bloggers are also used obviously more by female (male) bloggers. Thus, Articles, Business, Prepositions, Internet, Religion, and Politics are applied more by male bloggers and older bloggers, while Auxiliary Verbs, Conjunctions, Conversation, Personal Pronouns, At Home, Romance, Swearing, and Fun are applied more by female bloggers and younger bloggers. There are only 3 exceptions to this pattern: Family, applied more by females and by older bloggers; Music, applied more by males and by younger bloggers; and, School, for which there is no important difference between male and female usage.

The force of this observation is underlined when examining those personal words that show both strong age-linked and gender-linked effects. Argamon, et al. (2007:1) considers that the 316 words that are both the 1000 words with highest information got for age and the 1000 words with highest information got for gender.

\section{Standard Language vs Slang}

One of the factors that disturbs the development of Bahasa Indonesia (Standard Language) is the influence of "slang". If it's done in spoken language, texting, Twitter, or in TV shows, we can still understand. However, apparently, the use of unofficial language in activities 
like writing and speaking is often found in the classroom. On the test answer sheet, in students' assignment, and in presentations in front of the classes are still used slang language. Along with the development of the times, especially in Indonesia is increasingly seen the influence given by slang on the use of Bahasa Indonesia grammar. Using slang by the wider community has a negative impact on the development of Bahasa Indonesia as a national identity now and the future. Today, there are already many people use slang and even the younger generation of Indonesia is not separated from the use of this slang. Even this young generation is more often using slang than using Indonesian. For avoiding the use of very popular slang in the community, we should instill love in the nation's generation of Bahasa Indonesia as the national language. In international relations, Bahasa Indonesia embodies Indonesian national identity. Along with the emergence of slang in society, a lot of the impact or influence caused by slang language towards the development of Bahasa Indonesia as an identity among them is the existence of Bahasa Indonesia is threatened to be marginalized by slang. Effect of globalization in the nation's identity is reflected in the people's behavior that began to leave Bahasa Indonesia and tend to use slang (Rahayu, 2015: 5).

\section{Standard and Non-Standard Vocabulary}

In KBBI (Official Dictionary of Standard Bahasa Indonesia) Fourth Edition mentioned the meaning of standard is principal; applicable benchmarks for the quantity and quality that determined based on agreement; standard. The standard words are used in standardized contexts, both verbal and writing. While not-standard word is used in not-standard variety. The variety of standard languages can be limited with several points of view, including: (1) standpoint of rigidity, the language used, (2) standpoint of information, and (3) standpoint of user's language point of view. From the point of view language standardization, standard language is good grammar, vocabulary, and the grammar is in accordance with the results of language standardization. From the angle of information view, the standard language is variety of languages used in communicating knowledge. Then based on the angle of the user's point of view, variety of standard languages can be limited by variety of languages that commonly used by the most influential speakers, like scientists, governments, society figures, and journalists or reporter. Their language is the one considered a variety of standard languages (Mulyono in 
Chaer, 2011: 5 in Setiawati, 2016: 48).

\section{Dialect}

The term dialect is from the ancient Greek word used in two distinct ways. It refers to a variety of a language that is a characteristic of a particular group of the language's speakers (Oxford English dictionary). The term is applied most often to regional speech patterns, but a dialect may also be defined by other factors, such as social class (Merriam-Webster Online dictionary.) According to this definition, any variety of a language constitutes "a dialect", including any standard varieties. A dialect is distinguished by its vocabulary, grammar, and pronunciation. Furthermore, A standard dialect (also known as a standardized dialect or "standard language") is a dialect that is supported by institutions. Such institutional support may include government recognition or designation; presentation as being the "correct" form of a language in schools; published grammars, dictionaries, and textbooks that set forth a correct spoken and written form; and an extensive formal literature that employs that dialect (prose, poetry, non-fiction, etc.). Meanwhile, a nonstandard dialect, like a standard dialect, has a complete vocabulary, grammar, and syntax, but it is usually not the beneficiary of institutional support.

Miko's Saturday Night: The Car, Olive and Tara (Malam Minggu Miko eps. Mobil, Olive dan Tara)

Miko's Saturday Night is comedy series created by Raditya Dika, which besides he is the major player, he is also the producer, the writer and even the director in the comedy series making. Besides Raditya Dika, this series are also starred by Ryan Adriandhy and Hadian Saputra. It is aired weekly on Compass TV; there are two episodes in each of views and each of them lasted around 12 minutes.

Miko's Saturday Night shares the experience of a ridiculousness of Miko (Raditya Dika) and her best friend Rian (Ryan Adriandhy) who are always hit by turmoil and dilemmas dealing with girls every Saturday night of the week. They both live in a rented house, and had a maid named Anca (Hadian Saputra). Every time they want to have a girl is doomed to fail. 
In this episode; The Car, Olive and Tara which has duration 13:24, told us about Miko, Ryan and Anca who have own dating with girls in different setting but still 3 of them are in their each car. Miko with Olive and Olive's father in his car, Ryan and Tara in his car, and Anca and Maimunah in a taxi. They have each absurd story but unfortunately it ended with a fail dating and they must go to the Police Station because of different cases. Miko's case is alleged of consuming drugs, since Olive's father pretended to show of drugs he bought from drugstore only for making a joke to a policeman when there is a police raid. As a result, Miko must test his urine many times until he is dehidrated, to prove that he is free as a drug's consumer. Furthermore, Ryan's case is driving fast on the road because he did not endure with the way Tara's laugh. It is like a pig's sound. He said that he would rather stay at police station than listen to Tara's laugh. That's why he drove so fast. The last is Anca's case. He and his girl ride in a taxi that the driver know nothing about roads in Jakarta. Thus, they were lost in a dangerous place where 2 policemen are shooting at an illegal drugs distributor in front of the taxi. Consequently, Anca is considered as one of protected witnesses and he must be investigated in the same police station with Miko and Ryan. It means that again they all three did not enjoy their Saturday's Night and failed to have a girl.

\section{RESEARCH METHOD}

This type of this research is almost similar with a study did by Tupamahu (2017: 45). This research is applied descriptive qualitative research. In order to hold the research, all of the conversations were fully selected. The data was collected by online browsing to get the clear script of conversation.

The sample of the study is consisted of 2 parts which are divided into gender and age point of views based on the underlying theories. The conversations are categorized as: two languages (Bahasa Indonesia or the original language of the TV seri and English as the translation). The dialogs are also divided into standard language and non-standard language among adult male, females and older man (parents). The idea of this method is also influenced by a research conducted by Al-Harahsheh and Ahmad (2014: 873). 


\section{RESULTS \& DISCUSSION}

According to theories discussed above, this section will analyze the facts seen on the TV Series "Miko's Saturday Night: The Car, Olive and Tara". The first table is showing the data that are compared with Labov's statement (1990: 210), he confirms women tend to choose the standard variants more frequently than men. Then, the second one is presented data which is related to Downes (1984: 191); between the ages of 25 and 60 people choose standard as opposed to dialectical forms most frequently.

Table 1.1. Labov's statement in "Miko's Saturday Night: The Car, Olive and Tara" TV Series

\begin{tabular}{|c|c|c|c|}
\hline No. & $\begin{array}{l}\text { Indonesian } \\
\text { (Original) }\end{array}$ & $\begin{array}{l}\text { Indonesian Script } \\
\text { (The Standard Language) }\end{array}$ & English Script \\
\hline 1. & $\begin{array}{l}\text { Olive: sori ya Miko, bikin } \\
\text { lo lama nunggu } \\
\text { Miko: iya gak papa kok } \\
\text { nunggunya ga lama cuman } \\
2 \text { jam } \\
\text { O: oh,, ketebalan ga make } \\
\text { up gue? } \\
\text { M: ah ga, ga ketebelan kok, } \\
\text { gue pernah jalan ama cewe } \\
\text { yang lebih parah dari pada } \\
\text { itu, gue baru jalan } 2 x, \text { gue } \\
\text { udah kena TBC } \\
\text { O: TBC? } \\
\text { M: iya kata dokter paru- } \\
\text { paru gue kemasukan bedak }\end{array}$ & $\begin{array}{l}\text { Olive: maaf ya Miko, } \\
\text { membuat kamu lama } \\
\text { menunggu } \\
\text { Miko: iya tidak apa-apa } \\
\text { menunggunya tidak lama } \\
\text { hanya } 2 \text { jam } \\
\text { O: oh,,, apakah make up-ku } \\
\text { terlalu tebal? } \\
\text { M: ah tidak, tidak terlalu } \\
\text { tebal, aku pernah jalan } \\
\text { dengan gadis yang lebih } \\
\text { parah dari pada itu, aku } \\
\text { baru saja kencan } 2 \text { kali, } \\
\text { aku sudah terkena TBC } \\
\text { O: TBC? } \\
\text { M: iya, kata dokter paru- } \\
\text { paruku kemasukan bedak }\end{array}$ & $\begin{array}{l}\text { O: oh,,, is my make up too } \\
\text { thick? } \\
\mathrm{M} \text { : oh no, that's not too } \\
\text { thick anyway, I ever go } \\
\text { with a girl who is more } \\
\text { severe than that, I had dates } \\
\text { twice, I'd been suffered to } \\
\text { TBC }\end{array}$ \\
\hline
\end{tabular}




\begin{tabular}{|c|c|c|c|}
\hline & & & $\begin{array}{l}\text { M : Yeah, the doctor said } \\
\text { my lungs conceded the } \\
\text { powder }\end{array}$ \\
\hline 2. & $\begin{array}{l}\text { Tara: Ryan kok lo cepet } \\
\text { banget sih datangnya? Gue } \\
\text { baru aja selese makan } \\
\text { malam } \\
\text { Ryan: itu ada coklat di } \\
\text { bibir lu } \\
\text { Tara: ooh...hehe iya lupa.. } \\
\text { kok lo jemputnya cepet } \\
\text { banget sih yan? } \\
\text { Ryan: ya ga pa pa kalo kita } \\
\text { berangkatnya lebih cepet, } \\
\text { kita bisa dapet bangku } \\
\text { yang lebih enak buat } \\
\text { nonton } \\
\text { kaman safari??? Ya berarti } \\
\text { kita mau safari night donk? } \\
\text { nolawak gitu, cuma beda, } \\
\text { nonton apaan sih? Stand } \\
\text { comedo? Comodo? Ooh? } \\
\text { Mau nonton komodo ya? di } \\
\end{array}$ & $\begin{array}{l}\text { Tara: Ryan, kenapa kamu } \\
\text { sangat cepat datangnya? } \\
\text { Aku baru saja selesai } \\
\text { makan malam } \\
\text { Ryan: itu ada coklat di } \\
\text { bibirmu } \\
\text { Tara: ooh...hehe iya lupa.. } \\
\text { kenapa kamu } \\
\text { menjemputnya sangat } \\
\text { cepat, yan? } \\
\text { Ryan: ya tidak apa apa } \\
\text { kalau kita berangkatnya } \\
\text { lebih cepat, kita bisa dapat } \\
\text { bangku yang lebih enak } \\
\text { untuk menonton } \\
\text { Tara: memang kita akan } \\
\text { menonton apa? Stand } \\
\text { comedo? Comodo? Ooh.. } \\
\text { akan menonton komodo } \\
\text { ya? di taman safari??? Ya } \\
\text { berarti kita akan safari } \\
\text { night? } \\
\text { Ryan: bukan-bukan, ini } \\
\text { kitaakan lihat ini.. stand up } \\
\text { comedy. Jadi ini itu seperti } \\
\text { orangnyak itu, namun beda, } \\
\text { atu di atas }\end{array}$ & $\begin{array}{l}\text { Tara : Ryan, why do you so } \\
\text { fast to come? I've just } \\
\text { finished dinner } \\
\text { Ryan : That's chocolate in } \\
\text { your mouth } \\
\text { Tara : ooh ... hehe I forgot.. } \\
\text { why do you pick me up } \\
\text { quickly, yan? } \\
\text { Ryan : yeah it's better if we } \\
\text { depart more quickly, we } \\
\text { can get a more comfortable } \\
\text { seat to watch } \\
\text { Tara : what will we watch } \\
\text { exactly? Stand comedo? } \\
\text { Comodo? Ooh .. we will } \\
\text { watch the comodo? In the } \\
\text { safari park ??? Yeah, it } \\
\text { means that we will have } \\
\text { safari night? } \\
\text { Ryan: no no, we will look } \\
\text { at this .. stand up comedy. } \\
\text { by himself }\end{array}$ \\
\hline
\end{tabular}




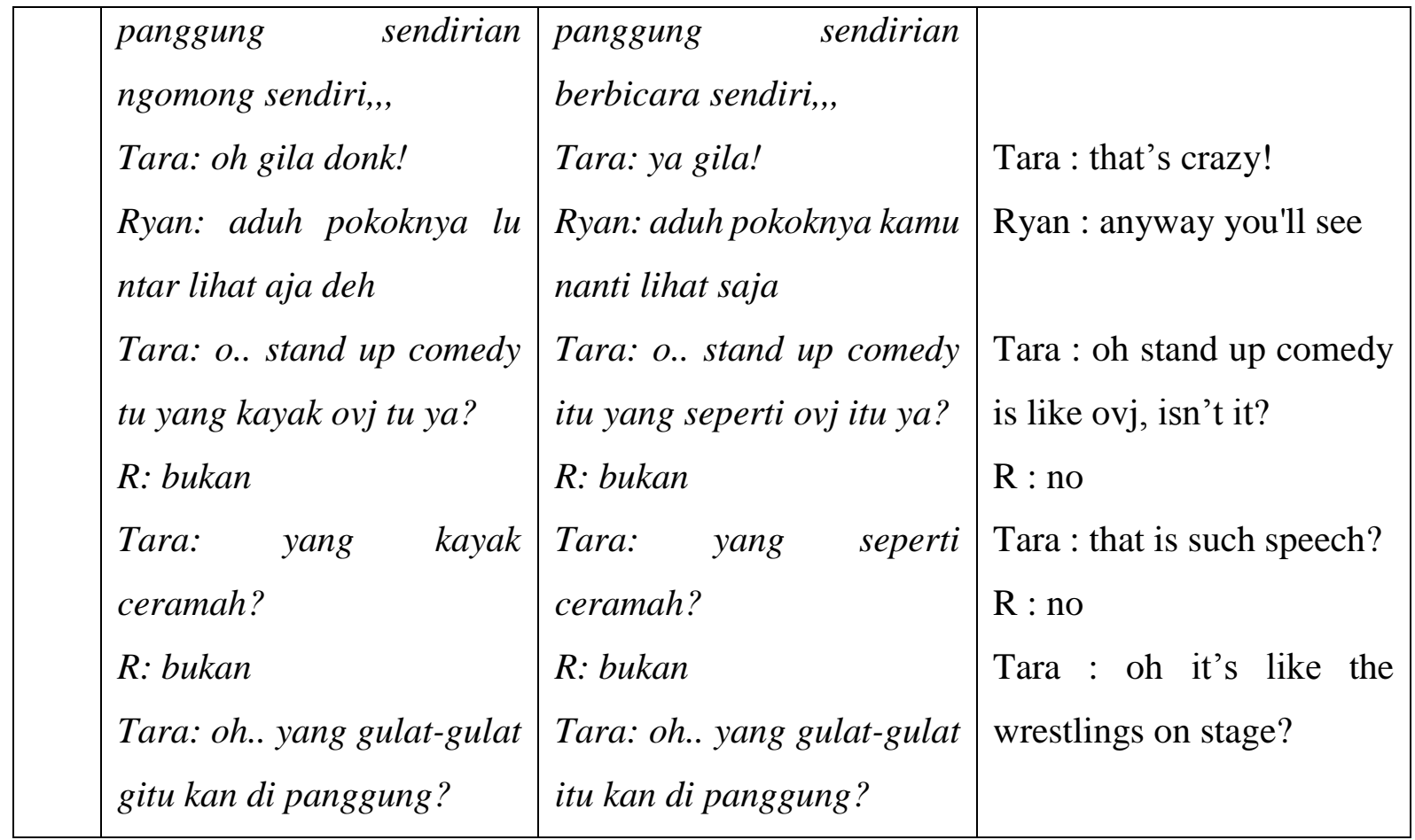

Table 1.2. Downes's statement in "Miko's Saturday Night: The Car, Olive and Tara" TV Series

\begin{tabular}{|c|c|c|c|}
\hline No. & $\begin{array}{ll}\text { Indonesian } & \text { Script } \\
\text { (Original) } & \end{array}$ & $\begin{array}{l}\text { Indonesian Script } \\
\text { (The Standard Language) }\end{array}$ & English Script \\
\hline 1. & $\begin{array}{l}\text { Ayah Olive: Kok kalian ga } \\
\text { ngomong-ngomong sih dari } \\
\text { tadi? } \\
\text { Miko: ga pa pa om } \\
\text { AO: ga enak ya sama om? } \\
\text { Sante aja, om gini-gini gaul } \\
\text { lo } \\
\text { M: o gitu ya om? }\end{array}$ & $\begin{array}{l}\text { Ayah Olive: Kalian tidak } \\
\text { mengobrol dari tadi? } \\
\text { Miko: tidak apa apa, Om } \\
\text { AO: Tidak enak ya dengan } \\
\text { om? Santai saja, om seperti } \\
\text { ini gaul } \\
\text { M: o begitu ya om? }\end{array}$ & $\begin{array}{l}\text { Miko : it's okay, Uncle } \\
\text { AO : feeling hesitant to me? } \\
\text { Dont worry, although I am an } \\
\text { uncle, but I can be like a cool } \\
\text { young man and knowing } \\
\text { slang words well } \\
\text { M : oh really, uncle? }\end{array}$ \\
\hline
\end{tabular}




\begin{tabular}{|c|c|c|c|}
\hline & $\begin{array}{l}\text { AO: Iyuuusss hehehehe gitu } \\
\text { kan ngomongnya? } \\
\text { Olive: ih papah alay banget } \\
\text { sih } \\
\text { AO: Eh kemarin, om itu } \\
\text { nyoba make skinny jeans } \\
\text { M: o gitu om } \\
\text { AO: Iya, biar gaul kan? } \\
\text { M: oh bagus om } \\
\text { AO: Ga enak tuh. Om malah } \\
\text { kesemutan }\end{array}$ & $\begin{array}{l}\text { AO: terus hehehehe seperti } \\
\text { itu kan mengucapkannya? } \\
\text { Olive: papah berlebihan } \\
\text { sekali } \\
\text { AO: Eh kemarin, om itu } \\
\text { mencoba memakai celana } \\
\text { jeans ketat } \\
\text { M: o begitu om } \\
\text { AO: Iya, supaya gaul kan? } \\
\text { M: oh bagus om } \\
\text { AO: tidak enak. Om jadi } \\
\text { kesemutan }\end{array}$ & $\begin{array}{l}\text { AO : and then hehehehe is it } \\
\text { correct to say like that? } \\
\text { Olive : daddy is so excessive } \\
\text { AO : Uh yesterday, I was } \\
\text { trying to wear tight jeans } \\
\text { M : oh really, uncle? } \\
\text { AO : Yes, in order to be a } \\
\text { young and cool man, right? } \\
\text { M : oh that's nice, uncle } \\
\text { AO : it isn't nice. I was so } \\
\text { numb }\end{array}$ \\
\hline 2. & $\begin{array}{l}\text { Ayah Olive: maaf ya lama } \\
\text { nunggu, obat om habis, jadi } \\
\text { ya harus beli dulu } \\
\text { Miko: ga pa pa kok om } \\
\text { AO: sekarang mau ke mana? } \\
\text { M: habis ni kami mau ke } \\
\text { restoran sih om } \\
\text { AO: hehe om ikut ya? } \\
\text { M: e... } \\
\text { AO: iya om ikut.. masak om } \\
\text { ga ikut, kamu tega om } \\
\text { kelaparan? }\end{array}$ & $\begin{array}{l}\text { Ayah Olive: maaf ya lama } \\
\text { menunggu, obat om habis, } \\
\text { jadi ya harus beli dulu } \\
\text { Miko: tidak apa apa kokom } \\
\text { AO: sekarang akan ke } \\
\text { mana? } \\
\text { M: setelah ini kami akan ke } \\
\text { restoran om } \\
\text { AO: hehe om ikut ya? } \\
\text { M: e... } \\
\text { AO: iya om ikut.. apakah } \\
\text { benar om tidak ikut, apakah } \\
\text { kamu tega om kelaparan? }\end{array}$ & $\begin{array}{l}\text { Olive 's father: I'm sorry for } \\
\text { waiting so long, my drugs } \\
\text { run out, so I should buy } \\
\text { Miko : no problem, uncle } \\
\text { AO : so where are we going } \\
\text { to go now? } \\
\text { M : after this we are going to } \\
\text { go to a restaurant, uncle } \\
\text { AO : hehe I join you, ok? } \\
\text { M : e ... } \\
\text { AO : yes, I join, are you } \\
\text { really? I do not come? You } \\
\text { want to put me in a hunger? }\end{array}$ \\
\hline 3. & $\begin{array}{l}\text { Ayah Olive: loh ada apa itu } \\
\text { di depan? } \\
\text { Miko: Aduh ada razia om, } \\
\text { kita disuruh minggir om }\end{array}$ & $\begin{array}{l}\text { Ayah Olive: ada apa itu di } \\
\text { depan? } \\
\text { Miko: Aduh ada razia om, } \\
\text { kita disuruh minggir om }\end{array}$ & $\begin{array}{l}\text { Olive 's father: what is } \\
\text { happening in front? }\end{array}$ \\
\hline
\end{tabular}




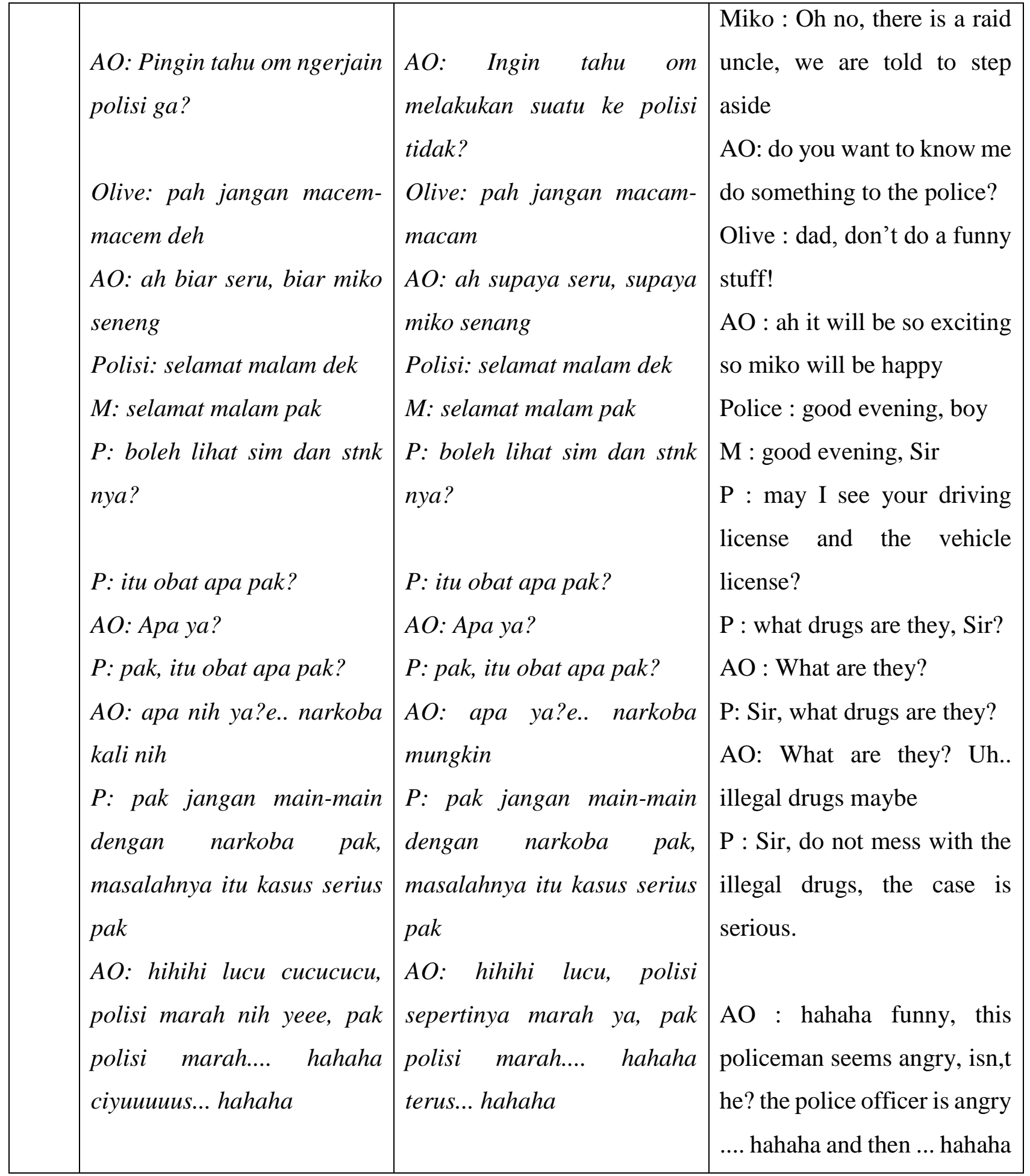

The first arrow on the table 1.1 shows that Olive as a girl in this drama used non standard variants of Indonesian language when she spoke to Miko, the boy. Why it is non- 
standard language? Because the words that she mostly used are included in Jakarta dialect and slang words such as sori ya (the standard is maaf ya-sorry), bikin lo (membuatmu-make you), ga (tidak-no), and gue (saya-I). These words are commonly only applied by youngsters especially in Jakarta. According to the theory above about standard language, it is the language taught in school or used in media and published by authorized instutitution or government in a country, so what Olive said could not be consider as standard language. Additionally, a dialect refers to a variety of a language that is a characteristic of a particular group of the language's speakers and Olive's dialect is considered as a nonstandard dialect which also has a complete vocabulary, grammar, and syntax but it is usually not the contribution of institutional support. This case also occured in the second arrow of the table. Tara did not talk to Ryan with standard language. She said lo (kamu-you), cepet (cepat-quick), banget (sangat-very), gue (saya-I), selese (selesai-end), nonton (menonton-watch), apaan (seperti apa-like what), donk (expression-no standard word), sih (expression-no standard word), kok (expression-no standard word), tu (adalah-to be), kayak (seperti-such/as), gitu kan (apakah seperti itu-is like that).

Based on those findings above, it can be seen that Labov's theory (1990: 210) confirms women tend to choose the standard variants more frequently than men, is not able to be proven in these facts. They are contradictory with Labov's statement. Olive and Tara's dialect in the dialog are simply similar to Miko and Ryan's dialect. On the other hand, they support the statement of Aldous Huxley "In the eighteen century, when logic and science were the fashion, women tried to talk like the men." Those cases also confirm this theory that no gender speaks a better language, but each gender instead speaks its own unique language (Masoud: 2011), so it is not true that women generally speak a better "language" then men do.

The second table presents three scenes acted by three and four people. The object that is observed is Olive's Father who is around $25-60$ years old. He is probably in 50's years old. However by observing his conversation to Miko and Olive, it is presented non standard language which is not supported by institutions such as government recognition and considered as the "correct" form of a language in schools; published grammars, dictionaries, and textbooks. In the first arrow, he said kok (expression-no standard word), ga (tidak-no), ngomong-ngomong (berbicara-talk to), sante aja (santai saja-easy), gini-gini (seperti ini-like this), gaul lo (gaya 
anak muda masa kini-youngsters), iyuиuиusss (terus-and then), gitu kan (seperti itu kan- is like that), nyoba make (mencoba memakai, trying to wear), biar gaul kan? (supaya seperti gaya anak muda masa kini-in order to be cool youngsters), tuh (expression-no standard word), malah (expression-no standard word). In the second, he said nunggu (menunggu-waiting for) and masak (benar-benar-really). At last, he said loh (expression-no standard word), pingin (inginwant), ngerjain (menjahili-cause trouble), seneng (senang-happy), nih (expression-no standard word), kali (mungkin-maybe), Іисисисисиси (lucu-funny), nih yee (expression-no standard word), ciуyииииииs (terus-and then).

After finding the utterances of Olive's Father, it violates Downes's theory (1984: 191) who says that between the ages of 25 and 60 people choose standard as opposed to dialectical forms most frequently (Coulmas: Chapter 4-Age, page 61). In addition, according to the Coulmas's book (p.61), as people grow older, their speech becomes less dialectical and converges toward the standard. In fact, what happened to Olive's father is not in line with this statement too.

\section{CONCLUSION}

To sum up, the two underlying theories (Labov and Downes) have been rejected by the facts occured in TV Series "Miko's Saturday Night eps. The Car, Olive and Tara". The gender phenomenon in the TV Series prove that women did not tend to choose the standard variants more frequently than men, because the women often used non standard varieties such as the men did. Then, the age facts show that between the ages of 25 and 60 people choose non standard language most frequently such as it happened to Olive's father who can talk like modern youngsters.

The change of language focuses when people are successful in determining gender, maintaining identity and blurring boundaries. That is why, in daily conversation, gender does not mean wrong but gender that determines identity is also inadequate. Hopefully, by learning this journal, the young people can maintain their standard language in academic purpose especially when they learn English in the classroom. 


\section{REFERENCES}

Al-Harahsheh, Ahmad Mohammad Ahmad. (2014). Language and Gender Differences in Jordanian Spoken Arabic: A Sociolinguistic Perspective. Theory and Practice in Language Studies, Vol. 4, No. 5, pp. 872-882. Yarmouk University, Irbid: Jordan

Argamon, S.; Koppel, M.; Pennebaker, J.; and Schler, J. 2007. Mining the blogosphere: age, gender, and the varieties of self-expression. First Monday 12(9).

Azizi, Masoud. (2013). "Language And Gender: Do women Speak A Better Language?" EProceedings of the International Online Language Conference (IOLC) 2: 90-93. Communication \& Mass Media Complete. Web. 1 May 2013

Biber, D., 1994. “An analytical framework for register studies,” In: D. Biber and E. Finegan (editors). Sociolinguistic perspectives on register. New York: Oxford University Press, pp. $31-56$.

Burger, J.D. and Henderson, J.C., 2006. “An exploration of observable features related to blogger age," In: Computational Approaches to Analyzing Weblogs: Papers from the 2006 AAAI Spring Symposium. Menlo Park, Calif.: AAAI Press, pp. 15-20.

Coulmas, Flourian. (2005). Sociolingustics: The Study of Speakers' Choices.Cambridge University Press

Downes, William. (1984). Language and Society. London: Fontana.

Fasold, Ralph. (2006). "The politics of language." In R.W. Fasold and J. Connor-Linton (eds) An Introduction to Language and Linguistics. pp. 371-400. Cambridge: Cambridge University Press.

Jule, Allyson. (2004). Gender, Participation and Silence in the Language Classroom. New York: Palgrave Macmillan.

Labov, William. (1990). The intersection of sex and social class in the course of linguistics change. Language Variation and Change 2: 205-54. 
Newman, M.L., C.J. Groom, L.D. Handelman, and J.W. Pennebaker, in press. "Gender differences in language use: An analysis of 14,000 text samples," Discourse Processes.

Pennebaker, J.W., M.R. Mehl, and K. Niederhoffer, 2003. "Psychological aspects of natural language use: Our words, ourselves," Annual Review of Psychology, volume 54, pp. 547-577. http://dx.doi.org/10.1146/annurev.psych.54.101601.145041

Rahayu, Arum Putri. (2015). Menumbuhkan Bahasa Indonesia yang Baik dan Benar dalam Pendidikan dan Pengajaran. JURNAL PARADIGMA Volume 2, Nomor 1, November 2015: ISSN 2406-9787

Romera, Magdalena. (2015). The Transmission of Gender Stereotypes in the Discourse of Public Educational Spaces. Discourse \& Society, Vol. 26(2) 205 -229

Schler, J., M. Koppel, S. Argamon, and J. Pennebaker, 2006. "Effects of age and gender on blogging," In: Computational Approaches to Analyzing Weblogs: Papers from the 2006 AAAI Spring Symposium. Menlo Park, Calif.: AAAI Press, pp. 199-205, and at http://lingcog.iit.edu/doc/springsymp-blogs-final.pdf, accessed 21 August 2007.

Setiawati, Sulis . (2016). PENGGUNAAN KAMUS BESAR BAHASA INDONESIA (KBBI) DALAM

PEMBELAJARAN KOSAKATA BAKU DAN TIDAK BAKU PADA SISWA KELAS IV SD. JURNAL GRAMATIKA. STKIP PGRI Sumatera Barat. Jurnal Penelitian Bahasa dan Sastra Indonesia V2.i1 (44-51). ISSN: 2442-8485 E-ISSN: 2460-6319

Trudgill, Peter. (1999), "Standard English: what it isn't". In T. Bex \& R.J. Watts (eds) Standard English: The Widening Debate. pp. 117-128. London: Routledge.

Tannen, Deborah (2006). "Language and culture". In Ralph W. Fasold and Jeff Connor-Linton. An Introduction to Language and Linguistics. Cambridge University Press. ISBN 0-52161235-7.

Tannen, Deborah (1990). You Just Don't Understand: Women and Men in Conversation. New York: Harper Collins. 
Tupamahu, Marissa Swanda. (2017). SOCIOLINGUISTIC PERSPECTIVE OF GENDER PATTERNS ON FACEBOOK. Sociolinguistic Perspective Of Gender. Volume 14,Nomor 2,Agustus 2017

Merriam-Webster Online dictionary.

Oxford English dictionary.

http://en.wikipedia.org/wiki/Variety_\%28linguistics\%29

http://id.wikipedia.org/wiki/Malam_Minggu_Miko 